KEMAS 11 (1) (2015) 25-31
Jttp://journal.unnes.ac.id/nju/index.php/kemas

\title{
FAKTOR DETERMINAN TOKSOPLASMOSIS PADA IBU HAMIL
}

\author{
Ani Triana ${ }^{\bowtie}$ \\ Program Studi D3 Kebidanan STIKes Hang Tuah Pekanbaru
}

\begin{tabular}{l} 
Info Artikel \\
\hline Sejarah Artikel: \\
Diterima 8 April 2015 \\
Disetujui 5 Juni 2015 \\
Dipublikasikan Juli 2015 \\
\hline Keywords: \\
Toxoplasmosis; \\
Pregnant; Job; Parity status \\
\hline DOI \\
http://dx.doi.org/10.15294/ \\
kemas.v11i1.3459 \\
\hline
\end{tabular}

\begin{abstract}
Abstrak
Toksoplasmosis merupakan penyakit yang disebabkan oleh Toxoplasma gondii yang merupakan golongan protozoa yang sifatnya parasite obligat intraseluler. Salah satu Provinsi terbesar di Indonesia yaitu Provinsi Riau terdapat kasus Toksoplasmosis yang menurut data dari rekam medis RSUD Arifin Achmad Provinsi Riau toksoplasmosis merupakan penyakit peringkat 9 tertinggi dari 15 penyakit terbesar dalam kehamilan. Tujuan penelitian ini untuk mengidentifikasi faktor determinan terjadinya toksoplasmosis pada ibu hamil di RSUD Arifin Achmad Provinsi Riau. Penelitian ini menggunakan jenis penelitian kuantitatif dengan desain penelitian case control. Populasi pada penelitian ini adalah seluruh ibu hamil yang tercatat di rekam medik RSUD Arifin Achmad pada tahun 2012 dengan jumlah sampel sebanyak 60 orang terbagi menjadi 30 orang sebagai kasus dan 30 orang sebagai kontrol (dengan teknik systematic random sampling). Pengumpulan data dilakukan dengan menggunakan kuesioner data analisis multivariat dengan uji multiple logistic regresion. Hasil penelitian menunjukkan adanya dua variabel yang berhubungan secara signifikan yaitu variabel pekerjaan dengan $p$ value $(0,008)$ OR: 7,97 ; CI 95\% $(1,70-37,34)$ dan status paritas dengan p value $(0,029)$ OR: 5,33 ; CI $95 \%(1,18-24,18)$.
\end{abstract}

\section{DETERMINANT FACTORS TOXOPLASMOSIS IN PREGNANT WOMEN}

\begin{abstract}
Toxoplasmosis is a disease caused by Toxoplasma gondii is a protozoan group obligate intracellular parasite nature. Riau province there are cases of toxoplasmosis which according to data from medical records General Hospital of Arifin Achmad in Riau Province toxoplasmosis is a disease of the 15 highest ranked 9th largest disease in pregnancy. The purpose of this study to identify the determinants of the occurrence of toxoplasmosis in pregnant women at General Hospital of Arifin Achmad in Riau Province. This research uses quantitative research with case-control study design. The population were all pregnant women recorded in the medical record Arifin Achmad Hospital in 2012 with sample of 60 people divided 30 people as cases and 30 persons as control (with a systematic random sampling technique). Data collection was performed using multivariate analysis of data questionnaire with multiple logistic regresion test. The results presence of two variabels significantly associated job with p value (0.008) OR: 7.97; 95\% CI (1.70 to 37.34) and parity status with p value (0.029) OR: 5.33; 95\% CI (1.18 to 24.18). Results of the study are expected to health workers to inform about toxoplasmosis complete and CHL counseling and regular prenatal care in the prevention of toxoplasmosis.
\end{abstract}

(C) 2015 Universitas Negeri Semarang

$\bowtie$ Alamat korespondensi:

Program Studi D3 Kebidanan STIKes Hang Tuah Pekanbaru

ISSN 1858-1196

Jl. Mustafa Sari No. 5, Kel.Tangkerang Selatan, Kec. Bukit Raya, Pekanbaru, Riau

Email: triana_aniz@yahoo.com 


\section{Pendahuluan}

Toksoplasmosis merupakan penyakit yang disebabkan oleh Toxoplasma gondii yang merupakan golongan protozoa yang sifatnya parasite obligat intraseluler. Penemu dari Toxoplasma gondii yang pertama kali adalah Nicole dan Splendore pada tahun 1908 pada hewan pengerat (tenodactylus gundii) pada bagian limfa dan hati di Tunisia Afrika dan pada seekor kelinci di Brazil dan disebut sebagai Toxoplasma gondii (Dubey, 2008).

Sekitar 30\% - 65\% dari populasi dunia adalah diperkirakan mengalami infeksi Toxoplasma kronis. Sebenarnya, prevalensi bervariasi antar negara (dari 10 sampai 80\%) dan sering dalam suatu negara tertentu atau antara komunitas yang berbeda di wilayah yang sama (Pappas G, 2009). Seroprevalences yang rendah (10 sampai 30\%) telah ditemukan di Amerika Utara, di Asia Tenggara, di Eropa Utara, dan di negara-negara Sahelian di Afrika. Prevalensi sedang (30 sampai 50\%) telah ditemukan di negara-negara Tengah dan Eropa Selatan, dan prevalensi tinggi telah ditemukan di Amerika Latin dan di negara-negara Afrika tropis (Robert, 2012).

Infeksi pada manusia dapat terjadi melalui tiga rute transmisi utama: makanan yang dikonsumsi (konsumsi daging yang terinfeksi oleh kista jaringan) (Montoya JG, 2004). Penularan hewan ke manusia (menelan ookista gudang dalam tinja kucing yang terinfeksi), dan ibu-ke-janin (infeksi kongenital melalui plasenta selama kehamilan) (Robert, 2012). Toksoplasmosis pada kehamilan menyebabkan infeksi Toxoplasma gondii pada janin melalui sirkulasi uteroplasenta. Ada korelasi positif yang sangat signifikan antara isolasi toksoplasmosis dari jaringan plasenta dan infeksi neonatal (Suparman, 2012).

Seroprevalensi toksoplasmosis diperkirakan bervariasi dari $<2 \%$ hingga $70 \%$ pada populasi di Asia Tenggara. Sayangnya, tidak ada studi tentang toxoplasmosis dilaporkan di Brunei Darussalam, meskipun kecil tapi negara tersebut kaya. Oleh karena itu, hanya 9 negara Asia Tenggara berdasarkan abjad yang berhasil melaporkan meliputi Kamboja (2001-2003), Indonesia (1965-2005), Laos PDR (1992), Malaysia (1973-2005), Myanmar (1977), Filipina (1991-2000), Singapura (1967-
2003), Thailand (1967-2004), dan Vietnam (1959-2003). Secara keseluruhan, jumlah total 103 publikasi yang berhasil dilaporkan (Nissapatorn, 2007).

Prevalensi toksoplasmosis di Indonesia yaitu 36,9\% dari populasi umum (1982-1994), 64\% dari orang di Jawa Timur (1992-1993), 7\% di Irian Jaya (1972), 3,1\% dari anak-anak dan remaja di Bali (Publikasi 1993), 9,7\% sampai 51\% di pedesaan Kalimantan Selatan (Kalimantan), $40 \%$ dari perempuan dan $50 \%$ dari perempuan di atas usia 10 tahun di Surabaya, 70\% dari orang dewasa di Jakarta, 8,4\% pasien HIVpositif di Jakarta (retinochoroiditis 2009) (Berger S, 2014). Toksoplasmosis pada darah donor di Bali adalah 35,9\%, sedangkan pada wanita adalah $63,9 \%$, 35\% sampai $73 \%$ dari kucing, $75 \%$ dari anjing, $11 \%$ sampai $36 \%$ dari babi, $24,4 \%$ dari ayam yang dijual bebas (2008 publikasi), 42\% dari daging kambing yang telah terinfeksi di Jakarta (2001) (Laksemi DAAS, 2013). Dari prevalensi an toksoplasmosis dan berbagai survei telah membuktikan bahwa di kota-kota besar di berbagai Provinsi di Indonesia masih relative tinggi kasus terjadinya toksopasmosis (Hanafiah M, 2010).

Salah satu provinsi terbesar di Indonesia yaitu Provinsi Riau terdapat kasus toksoplasmosis yang menurut data dari rekam medis RSUD Arifin Achmad Provinsi Riau toksoplasmosis merupakan penyakit peringkat 9 tertinggi dari 15 penyakit terbesar dalam kehamilan. Adapun proporsi kejadian toksoplasmosis di RSUD Arifin Achmad Provinsi Riau pada tahun 2010 yaitu sebanyak 13 orang $(1,2 \%)$ dari 1084 kunjungan kehamilan, sedangkan pada tahun 2011 ibu hamil yang positif mengalami toksoplasmosis tercatat 19 orang $(1,9 \%)$ dari 1010 kunjungan kehamilan dan pada tahun 2012 ibu hamil yang mengalami toksoplasmosis tercatat sebanyak 30 orang (2,3\%) dari 1303 kunjungan kehamilan (Rekam Medis RSUD Arifin Achmad Provinsi Riau, 2012). Kasus toksoplasmosis mengalami peningkatan. Tujuan penelitian ini untuk mengidentifikasi faktor determinan terjadinya toksoplasmosis pada ibu hamil di RSUD Arifin Achmad Provinsi Riau.

\section{Metode}

Penelitian ini merupakan penelitian 
analitik kuantitatif dengan desain studi kasus kontrol, yaitu rancangan penelitian yang membandingkan antara kelompok kasus dengan kelompok control untuk mengetahui proporsi kejadian berdasarkan riwayat ada tidaknya paparan.

Populasi adalah menjadi objek penelitian adalah seluruh ibu hamil yang tercatat di rekam medik RSUD Arifin Achmad Provinsi Riau tahun 2012 dengan keseluruhan sampel berjumlah 60 orang yang terbagi atas 30 orang sebagai kasus dengan kriteria inklusi yaitu ibu hamil yang mengalami toksoplasmosis dan terdata di RSUD Arifin Achmad Provinsi Riau pada tahun 2012 dan 30 orang sebagai kelompok kontrol dengan kriteria inklusi yaitu ibu hamil yang tidak mengalami toksoplasmosis dan terdata di RSUD Arifin Achmad Provinsi Riau pada tahun 2012 dan untuk kriteria ekslusi yaitu ibu hamil yang tidak lengkap datanya di rekam medis RSUD Arifin Achmad Provinsi Riau dan telah meninggal dunia. Pada kelompok kontrol pengambilan sampel dengan menggunakan systematic random sampling. Jenis data yang dikumpulkan adalah data primer dari variabel independen dan variabel dependen, yang mana sumber datanya adalah responden itu sendiri dan data sekunder yang sumber datanya adalah dari data Rekam Medis RSUD Arifin Achmad Provinsi Riau. Untuk pengumpulan data primer tersebut dilakukan wawancara terstruktur kepada responden dengan menggunakan instrument kuesioner. Penelitian ini dilakukan pada bulan April sampai dengan Juni 2013. Variabel dependen pada penelitian ini adalah kejadian toksoplasmosis, sedangkan variabel independennya adalah pekerjaan, status paritas, status pendidikan, pola mengkonsumsi makanan, kebiasaan menyentuh tanah dan transfusi darah.

Dalam penelitian ini analisa data dilakukan secara univariat, bivariat menggunakan analisis chi-square dan analisis multivariate menggunakan uji multiple logistic regresion.

\section{Hasil dan Pembahasan}

Berdasarkan distribusi dan karakterstik ibu hamil menurut kejadian toksoplasmosis pada pekerjaan sebagian besar ibu hamil memiliki pekerjaan tidak berisiko sebanyak
34 orang $(56,7 \%)$, namun tidak berselisih jauh dengan ibu yang memiliki pekerjaan yang berisiko 26 orang (43,3\%). Status paritas ibu hamil sebagian besar ibu dengan primigravida yaitu sebanyak 32 orang $(53,3 \%)$, ibu hamil sebagian besar memiliki pendidikan tinggi yaitu sebanyak 36 orang (60\%), sebagian besar ibu hamil mempunyai pola konsumsi makanan yang baik sebanyak 45 orang (75\%). Ibu hamil juga sebagian besar tidak mempunyai kebiasaan menyentuh tanah 35 orang $(58,3 \%)$ tetapi tidak berselisih jauh dengan ibu yang mempunyai kebiasaan menyentuh tanah yaitu sebanyak 25 orang $(41,7 \%)$ dan sebagian besar ibu hamil tidak pernah melakukan transfusi darah yaitu sebanyak 56 orang $(93,3 \%)$ (Tabel 1).

Berdasarkan hasil analisis bivariat terdapat empat variabel yang berhubungan

Tabel 1. Distribusi dan Karakteristik Ibu Hamil

\begin{tabular}{lcc}
\hline \multicolumn{1}{c}{ Variabel } & N & \% \\
\hline Pekerjaan & & \\
Beresiko & 26 & 43,3 \\
Tidak beresiko & 34 & 56,7 \\
$\begin{array}{l}\text { Status paritas } \\
\text { Primigravida }\end{array}$ & 32 & 53,3 \\
Multigravida & 28 & 46,7 \\
Status pendidikan & & \\
Rendah & 24 & 40 \\
Tinggi & 36 & 60 \\
Pola mengkonsumsi makanan & & \\
Buruk & 15 & 25 \\
Baik & 45 & 75 \\
Kebiasaan menyentuh tanah & & \\
Ya & 25 & 41,7 \\
Tidak & 35 & 58,3 \\
Transfusi Darah & & \\
Pernah & 4 & 6,7 \\
Tidak Pernah & 56 & 93,3 \\
\hline
\end{tabular}

Sumber:Data Primer

signifikan dengan kejadian Toksoplasmosis dengan $p$ value $<0,05$ yaitu pekerjaan $\mathrm{OR}$ : 17,87 CI $95 \%(4,74-67,43)$ status paritas OR : 4,03 CI 95\% (1,37-11,84), status pendidikan (OR : 6,00 CI 95\% (1,89-19,04)), dan kebiasaan menyentuh tanah (OR : 6,91 CI 95\% (2,1622,09)), sedangkan dua variabel yang tidak berhubungan signifikan dengan kejadian toksoplasmosis dengan $p$ value $>0,05$ yaitu pola mengkonsumsi makanan (OR : 0,84 CI 95\% 
Tabel 2. Hubungan Pekerjaan, Status Paritas, Status Pendidikan, Pola Mengkonsumsi Makanan, Kebiasaan Menyentuh Tanah, Transfusi Darah dengan Kejadian Toksoplasmosis di RSUD Arifin Achmad Provinsi Riau Tahun 2012

\begin{tabular}{|c|c|c|c|c|c|c|c|c|}
\hline \multirow{3}{*}{ Variabel } & \multicolumn{6}{|c|}{ Kejadian Toksoplasmosis } & \multirow{3}{*}{$\begin{array}{c}(P \\
\text { Value })\end{array}$} & \multirow{3}{*}{$\begin{array}{c}\text { OR/ } \\
\text { (CI 95\%) }\end{array}$} \\
\hline & \multicolumn{2}{|c|}{ Kasus } & \multicolumn{2}{|c|}{ Kontrol } & \multirow[t]{2}{*}{$\mathrm{N}$} & \multirow[t]{2}{*}{$\%$} & & \\
\hline & $\mathrm{n}$ & $\%$ & $\mathrm{n}$ & $\%$ & & & & \\
\hline \multicolumn{9}{|l|}{ Pekerjaan } \\
\hline Beresik0 & 22 & 73,3 & 4 & 13,3 & 26 & 43,3 & \multirow[t]{2}{*}{$<0,001$} & 17,875 \\
\hline Tidak beresiko & 8 & 26,7 & 26 & 86,7 & 34 & 56,7 & & $\begin{array}{l}(4,738- \\
67,434)\end{array}$ \\
\hline \multicolumn{9}{|l|}{ Status paritas } \\
\hline Primigravida & 21 & 70 & 11 & 36,7 & 32 & 53,3 & \multirow[t]{2}{*}{0,020} & $4,030(1,372-$ \\
\hline Multigravida & 9 & 30 & 19 & 63,3 & 28 & 46,7 & & $11,839)$ \\
\hline \multicolumn{9}{|c|}{ Status pendidikan } \\
\hline Rendah & 18 & 60 & 6 & 20 & 24 & 40 & \multirow[t]{2}{*}{0,004} & $6,000(1,890-$ \\
\hline Tinggi & 12 & 40 & 24 & 80 & 36 & 60 & & $19,043)$ \\
\hline \multicolumn{9}{|c|}{$\begin{array}{l}\text { Pola mengkonsumsi } \\
\text { makanan }\end{array}$} \\
\hline Buruk & 7 & 23,3 & 8 & 26,7 & 15 & 25 & \multirow[t]{2}{*}{1,000} & \multirow{2}{*}{$\begin{array}{c}0,837(0,260- \\
2,699)\end{array}$} \\
\hline Baik & 23 & 76,7 & 22 & 73,3 & 45 & 75 & & \\
\hline \multicolumn{9}{|c|}{$\begin{array}{l}\text { Kebiasaan } \\
\text { menyentuh tanah }\end{array}$} \\
\hline Ya & 19 & 63,3 & 6 & 20 & 25 & 41,7 & \multirow[t]{2}{*}{0,002} & \multirow{2}{*}{$\begin{array}{c}6,909(2,160- \\
22,098)\end{array}$} \\
\hline Tidak & 11 & 36,7 & 24 & 80 & 35 & 58,3 & & \\
\hline \multicolumn{9}{|c|}{ Transfusi Darah } \\
\hline Pernah & 1 & 3,3 & 3 & 10 & 4 & 6,7 & \multirow[t]{2}{*}{0,605} & \multirow{2}{*}{$\begin{array}{c}0,310(0,030- \\
3,168)\end{array}$} \\
\hline Tidak Pernah & 29 & 96,7 & 27 & 90 & 56 & 93,3 & & \\
\hline
\end{tabular}

Sumber: Data Primer

$(0,26-2,70))$ dan transfusi darah (OR : 0,31 CI 95\% (0,03-3,17)) (Tabel 2).

Variabel yang masuk ke dalam permodelan multivariat setelah dilakukan seleksi bivariate adalah pekerjaan, status paritas, status pendidikan dan kebiasaan menyentuh tanah dengan nilai $p$ value $\leq 0,25$. Berdasarkan pada permodelan multivariate terakhir yang menunjukkan risiko yang bermakna dengan $p$ value $<0,05$ yaitu pekerjaan dan status pendidikan sedangkan variabel status pendidikan dan kebiasaan menyentuh tanah menjadi tidak bermakna ( $p$ value $>0,05$ ) dan merupakan sebagai variabel pengganggu karena mengalami perubahan OR 10\% sehingga dimasukkan kembali kedalam permodelan.

Berdasarkan tabel 3 diatas adapun variabel yang berhubungan signifikan yaitu variabel pekerjaan dengan $p$ value 0,008 $(<0,05)$, OR 7,97 CI 95\% $(1,70-37,35)$ dan variabel status paritas dengan p value 0,029 (< 0,05), OR 5,34 CI 95\% $(1,18-24,18)$ sedangkan variabel yang tidak berhubungan signifikan yaitu variabel status pendidikan dengan $p$ value

Tabel 3. Faktor-faktor Dominan yang Mempengaruhi Kejadian Toksoplasmosis di RSUD Arifin Achmad Provinsi Riau Tahun 2012

\begin{tabular}{lcccc}
\hline \multirow{2}{*}{ Variabel } & \multirow{2}{*}{ P value } & \multirow{2}{*}{ OR } & \multicolumn{2}{c}{ CI 95\% } \\
\cline { 5 - 6 } & & & Lower & Upper \\
\hline Pekerjaan & 0,008 & 7,97 & 1,70 & 37,35 \\
Status paritas & 0,029 & 5,34 & 1,18 & 24,18 \\
Status pendidikan & 0,331 & 2,19 & 0,45 & 10,71 \\
Kebiasaan menyentuh tanah & 0,121 & 3,71 & 0,71 & 19,42 \\
\hline S
\end{tabular}

Sumber : Data Primer 
$0,331(\geq 0,05)$, OR 2,19 CI $95 \%(0,45-10,71)$ dan kebiasaan menyentuh tanah dengan $\mathrm{p}$ value 0,121 ( $\geq 0,05)$ CI 95\% (0,71-1942).

Pada penelitian ini ditemukan bahwa ibu yang pekerjaannya berisiko (seperti pekerja peternakan/pemotongan hewan, berkebun/petani) lebih berisiko 8 kali terinfeksi toksoplasmosis dibandingkan ibu yang pekerjaannya tidak berisiko. Hal ini dapat dilihat bahwa ibu dengan toksoplasmosis (kasus) berjumlah 22 orang (73,3\%) memiliki pekerjaan yang berisiko dan ibu yang tidak terinfeksi toksoplasmosis (kontrol) hanya berjumlah 4 orang $(13,3 \%)$ memiliki pekerjaan yang berisiko. Penelitian Rohmawati (2013), juga menyatakan bahwa ada hubungan yang signifikan antara kebiasaan pekerjaan berkebun dengan kejadian toksoplasmosis dengan $\mathrm{p}$ value $0,011(<0,05)$, OR 0,083 CI 95\% $(0,003-2,063)$. Penelitian ini juga sesuai dengan penelitian yang dilakukan. Agustiantiningsih (2013) yang menyatakan bahwa jenis pekerjaan berhubungan dengan praktik pencegahan filariasis dengan nilai $p$ value $0,047(<0,05)$.

Pada penelitian ini variabel pekerjaan sebagai variabel pengganggu dengan kebiasaan menyentuh tanah, hal ini dikarenakan pekerjaan yang berisiko terhadap kejadian toksoplasmosis salah satunya adalah berkebun yang sebagian besar aktivitas pekerjaannya menyentuh tanah. Aktivitas pada kelompok yang sering kontak dengan tanah yang tercemar ookista merupakan kelompok risiko tinggi tertular toksoplasmosis. Perlu diketahui bahwa transmisi penyebaran toksoplasmosis melalui tanah tercemar ookista yang bersporulasi bisa bertahan di tanah sampai beberapa bulan (Rohmawati, 2013). Kebanyakan petani telah tinggal di ladang mereka untuk jangka waktu lebih dari sepuluh tahun. Hal ini menunjukkan bahwa ada beberapa stabilitas dalam pajanan lingkungan terhadap setiap parasit selama periode waktu yang diperpanjang (Ogendi E, 2013). Pada penelitian D, Cvetkovic, (2010) didapatkan risiko infeksi secara signifikan (RR $=1,946,95 \% \mathrm{CI}=1,026-3,692, \mathrm{p}$ value 0,042 $(<0,05))$ meningkat pada wanita yang terpajan pada tanah.

Pekerjaan juga mengalami confounding dengan pendidikan hal ini sesuai dengan penelitian Jones JL (2001), tingkat pendidikan yang lebih rendah berhubungan dengan status sosial ekonomi rendah dan mungkin berhubungan dengan pekerjaan yang pekerjaannya berhubungan sebagian besar terpapar dengan tanah. Menurut Ogendi, E (2013), sebagian besar petani yang memiliki tingkat pendidikan mulai dari dasar sampai tinggi memungkinkan mereka memudahkan untuk melakukan perbaikan pengelolaan rumah tangga dan praktek pertanian untuk mencegah penularan dari ternak ke manusia.

Pada penelitian ini juga ditemukan bahwa ibu dengan status paritas primigravida lebih berisiko 5 kali terinfeksi toksoplasmosis dibandingkan ibu dengan status paritas multigravida. Hal ini dapat dilihat bahwa ibu dengan toksoplasmosis (kasus) berjumlah 21 orang (70\%) memiliki status paritas yang berisiko (primigravida) dan ibu yang tidak terinfeksi toksoplasmosis (kontrol) hanya berjumlah 11 orang $(36,7 \%)$ memiliki status paritas yang berisiko (primigravida). Penelitian ini sejalan dengan penelitian Mahmudah (2011), yang menyatakan bahwa ada hubungan antara paritas dengan kematian perinatal dengan $p$ value $0,016(<0,05)$, OR 2,99. Pada penelitian Laboudi (2014), didapatkan dari data faktor-faktor risiko yang dievaluasi yang dikaitkan dengan serologi untuk anti $\mathrm{T}$ antibodi toksoplasmosis gondii salah satunya yaitu paritas menunjukkan hubungan yang signifikan $(\mathrm{p}<0,05)$ dengan adanya antibody IgG pada seroprevalensi toksoplasmosis. Ini dapat dijelaskan melalui peningkatan paparan sumber infeksi disepanjang hidupnya. Pada penelitian Fallah (2008), dari 576 ibu primigravida yang dilakukan pemeriksaan prevalensi antibodi toksoplasmosis terdapat 193 orang $(33,5 \%)$ positif ditemukan antibosi toksoplasmosis (dengan titer $\geq 1: 20$ ) hal ini disebabkan oleh usia, konsumsi daging segar yang kurang matang dan sering mengkonsumsi sayuran mentah berhubungan signifikan secara statistik dengan tingkat infeksi yang lebih tinggi.

Pada penelitian ini paritas counfounding dengan kebiasaan menyentuh tanah dapat dilihat dari hasil penelitian bahwa 19 orang $(63,3 \%)$ ibu dengan toksoplasmosis dan 6 orang (20\%) memiliki kebiasaan menyentuh tanah, hal ini dapat disebabkan karena 
kurangnya pengetahuan tentang penyakit ini dan adanya hubungan toksoplasmosis terutama dengan aktivitas kebiasaan menyentuh tanah (Laboudi, 2014). Dapat disimpulkan bahwa pada paritas primigravida yang baru pertama kali mengalami kehamilan kurang mengetahui tentang toksoplasmosis, sehingga tidak dapat melakukan pencegahan terhadap penyakit ini khususnya pada primigravida yang memiliki kebiasaan menyentuh tanah seperti berkebun, petani dan bercocok tanam. Dalam sejumlah penelitian menyebutkan bahwa kontak dengan tanah, berkebun dan pekerjaan tanah telah terbukti berhubungan menjadi faktor risiko toksoplasmosis (Kolbekova P, 2007).

Perlu direkomendasikan kepada para tenaga kesehatan untuk melakukan screening toksoplasmosis pada saat masa kehamilan sebagai upaya pencegahan dan pemberian konseling ataupun penyuluhan tentang toksoplasmosis secara lengkap dan jelas ataupun disertai pembagian brosur agar mudah dibaca oleh ibu-ibu hamil sebagai bentuk peningkatan pengetahuan ibu hamil terhadap suatu penyakit misalnya informasi upaya pencegahan toksoplasmosis yang harus difokuskan terutama pada pencegahan penularan toksoplasmosis dari hewan ke manusia salah satunya pencegahan kebiasaan menyentuh tanah bagi ibu-ibu yang suka berkebun, bercocok tanam ataupun bertani. Oleh karena itu disarankan juga kepada para ibu hamil untuk melakukan pemeriksaan kehamilan secara rutin minimal 4 kali selama kehamilan agar penyakit dan komplikasi kehamilan dapat terdeteksi sejak dini terutama ibu primigravida yang baru pertama kali mengalami kehamilan yang belum mengetahui risiko kehamilan yang kemungkinan dapat diderita oleh ibu.

\section{Penutup}

Dari hasil penelitian ini dapat disimpulkan bahwa berdasarkan hasil analisis multivariat, faktor determinan risiko yang berpengaruh terhadap kejadian toksoplasmosis pada ibu hamil adalah pendidikan 0,008 $(<0,05)$, OR 7,97 ; CI $95 \%(1,70-37,35)$ dan status paritas nilai p $0,029(<0,05)$, OR 5,34; CI $95 \%(1,18-24,18)$. Adapun variabel yang tidak berhubungan pada penelitian ini yaitu variabel status pendidikan dengan nilai p 0,331 $(\geq 0,05)$, OR 2,19 CI 95\% (0,45-10,71) dan kebiasaan menyentuh tanah dengan $\mathrm{p}$ value $0,121(\geq$ 0,05) CI 95\% (0,71-1942), variabel tersebut dari hasil analisis multivariat merupakan varibel pengganggu.

\section{Ucapan Terima Kasih}

Peneliti mengucapkan terima kasih banyak kepada seluruh pihak RSUD Arifin Achmad Provinsi Riau yang telah memberikan izin penelitian dan pihak STIKes Hang Tuah yang telah memfasilitasi kegiatan penelitian ini.

\section{Daftar Pustaka}

Agustiantiningsih D. 2013. Praktik pencegahan filariasis. Jurnal Kesehatan Masyarakat Universitas Negeri Semarang (Unnes). 8 (2): 190-197.

Berger S. 2014. Infectious diseases of Indonesia. California, USA: GIDEON.

D Cvetkovic, et.al. 2010. Risk factors for toxoplasma infection in pregnant women in FYR of Dubey JP. 2008. The history of toxoplasma gondii the first 100 years. Journal Eukaryot Microbiol. 55 (6): 467-475.

Fallah M, et.al. 2008. Seroepidemiology of toxoplasmosis in primigravida women in hamdan islamic republic of iran 2004. Eastern Mediterranean Health Journal. 14 (1): 163-171.

Hanafiah M, et.al. 2010. Studi infeksi toksoplasmosis pada manusia dan hubungannya dengan hewan di banda aceh. Jurnal Kedokteran Hewan. 4 (2): 87-92.

Jones JL, et.al. 2001. Toxoplasma gondii infection in united states: seroprevalence and risk factors. American Journal of Epidemiology (AJE).

Laboudi M, Mansouri BE, Rhajaoui M. 2014. The role of the parity and age in acquisition of toxoplasmosis among pregnant women in rabat-morocco. International of Toxoplasmosis of Journal of Innovation and Applied Studies.

Laksemi DAAS, Artama WT, Wijayanti MA. 2013. Seroprevalensi yang tinggi dan faktor-faktor risiko toksoplasmosis pada donor darah dan wanita di bali. Jurnal Veteriner. 14 (2): 204212.

Mahmudah U, Cahyati WH, Wahyuningsih AS. 2011. Jurnal Kesehatan Masyarakat Universitas Negeri Semarang (Unnes). 7 (1): 41-50.

Montoya JG dan Liesenfeld O. 2004. Toxoplasmosis. 
Lancet. 363: 1965-1976. doi:10.1016/s01406736(04)16412-x.

Nissapatorn V. 2007. Toxoplasmosis: a silent threat in southeast asia. Research Journal Parasitology. 2 (1): 1-12.

Ogendi E, et.al. 2013. Questionnaire survey on the occurrence of risk factors for toxoplasma gondii infection amongst farmers in thika district Kenya. Journal of the South African Veterinary Association.

Pappas G, Roussos N, Falagas ME. 2009. Toxoplasmosis snapshots: global status of toxoplasma gondii seroprevalence and implications for pregnancy and congenital toxoplasmosis. International Journal Parasitol (serial on the internet).
Rekam Medis RSUD Arifin Achmad Provinsi Riau. 2012. Data Rekam Medis Penyakit Kehamilan Tahun 2010-2012. Pekanbaru: RSUD Arifin Achmad Provinsi Riau.

Robert-Gangneux F, Darde ML. 2012. Epidemiology of and diagnostic strategis for toxoplasmosis. Clin Microbiol Reviews, American Society for Microbiology (ASM) Journals (serial on the internet).

Rohmawati I, Wibowo A. 2013. Hubungan kejadian abortus dengan toxoplasmosis di puskesmas mentaras kabupaten gresik. Jurnal Biometrika dan Kependudukan. 2 (2): 173-181.

Suparman E. 2012. Toksoplasmosis dalam kehamilan. Jurnal Biomedik (serial on the internet). (cited 2014 December 23); 4 (1). 